\title{
INVENSI DESAIN KEMASAN PADA USAHA KECIL MENENGAH (UKM) "AL FAZZA" DI DESA SEI ROTAN
}

\author{
Adek Cerah Kurnia Azis ${ }^{1}$ \\ Putri Sari Margaret Julianty Silaban ${ }^{2}$ \\ Pebri Hastuti ${ }^{3}$ \\ Revita Yuni ${ }^{4}$
}

\author{
Pendidikan Seni Rupa, Fakultas Bahasa dan Seni ${ }^{1}$ \\ Pendidikan Ekonomi, Fakultas Ekonomi ${ }^{2,3}$, dan 4 \\ Universitas Negeri Medan \\ J1. Willem Iskandar Pasar V Medan Estate, Kec. Percut Sei Tuan, Keb. Deli Serdang, Provinsi \\ Sumatera Utara, Kode Pos 20371 \\ adekcerah@unimed.ac.id \\ poetrisilaban@unimed.ac.id \\ pebrihastuti@unimed.ac.id \\ revitayuni@unimed.ac.id
}

\begin{abstract}
ABSTRAK
Adapun yang menjadi tujuan dalam kegiatan Pengabdian Kepada Masyarakat yang dilaksanakan pada kelompok Usaha Kecil Menengah (UKM) "Al Fazza" di Desa Sei Rotan, Kecamatan Percut Sei Tuan, Kabupaten Langkat, Provinsi Sumatera Utara. UKM ini dikelola Bapak Roni Afriadi. Usaha kuliner ini berupa ; rujak cireng, rolade chicken, sirup rimpang jahe, sirup kunyit asam, dan pempek. UKM ini berbentuk usaha rumahan dimana produk yang dihasilkan dipasarkan dari Desa Sei Rotan hingga ke desa lainnya yang ada di Kabupaten Deli Serdang, hingga ke Kota Medan. Bentuk pengabdian ini luarannya, yaitu menghasilkan sebuah desain kemasan yang baik dan menarik, sehingga produk yang dihasilkan oleh mitra telah memiliki merek dagang, dengan mempertimbangkan berbagai macam unsur-unsur seni rupa dan tidak lepas dari apa yang disebut dengan prinsip-prinsip seni rupa tentunya. Diharapkan kegiatan ini akan memberikan manfaat yang berarti bagi mitra dan kedepannya usaha yang dikelola menjadi lebih baik dan meningkat dari tahun ke tahun baik segi penjualan, produksi dan inovasi terhadap bentuk dan cita rasa.
\end{abstract}

Kata Kunci: invensi; UKM; sei; rotan. 


\section{PENDAHULUAN}

Sei Rotan adalah Desa di Kecamatan Percut Sei Tuan, Kabupaten Deli Serdang, Provinsi Sumatera Utara, Indonesia, yang berdiri sejak tahun 1961. Desa Sei Rotan sendiri merupakan pemekaran dari Kampung Sei Rotan yang dahulunya adalah Perkebunan Tembakau PTP-IX, (Wikipedia, 2018). Desa Sei Rotan ini merupakan bekas tanah jaluran yang dibuka dan ditempati oleh etnis Melayu pada tahun 1935 dan Jawa pada tahun 1945. Seirig dengan berjalannya waktu, Desa Sei Rotan sudah dihuni oleh berbagai macam etnis seperti Mandailing, Batak, Minang, dan etnis-etnis lainnya. Desa yang memiliki jumlah penduduk hingga mencapai 10.747 jiwa ini pada tahun 2000 (Wikipedia, 2018), dan hingga tahun sekrang ini terus mengalami peningkatan.

Peningkatan pertumbuhan penduduk yang ada di desa ini tentunya berdampak terhadap pertumbuhan ekonomi masyarakat sekitarnya, kebutuhan hidup yang terus mengalami peningkatan khususnya dalam segi ekonomi Hall 52 membuat masyarakat berfikir untuk mengembangkan diri dalam berbagai kreativitas yang dapat meningkatkan pemberdayaan keluarga tentunya. Dilihat dari segi kreativitas tersebut ada beberapa Usaha Kecil Menengah (UKM) yang dikembangkan oleh masyarakat, di antaranya usaha yang dikelola oleh Bapak Roni Afriadi, usaha yang dikembangkan ini dalam segi kuliner yaitu berupa Rujak Cireng, Rolade Chicken, Sirup Rimpang Jahe, Sirup Kunyit Asam, dan Pempek.

UKM ini dalam bentuk usaha rumahan, dimana Bapak Roni yang akrap disapa ini memasarkan produknya dari Desa Sei Rotan hingga ke desa lainnya yang ada di Kabupaten Deli Serdang, namun tidak jarang juga hingga ke Kota Medan, di lokasi lapangan merdeka Medan. 
Berbicara soal rasa dan kegigihan Pak Roni dalam membuat dan memasarkan produknya tidak perlu diragukan lagi, produk yang dihasilkan sangat lezat hal ini terbukti dengan banyaknya pesanan yang diorder oleh berbagai kalangan yang menghubungi beliau melalui nomor WhatsApp yang diberikan ketika ada pembeli yang berminat untuk membeli kembali produk tersebut, namun dibalik itu semua ada sedikit kelemahan yang perlu ditingkatkan nilainya yaitu dari segi branding dimana produk yang dihasilkan belum dibubuhi dengan ilustrasi, merek, slogan, komposisi, alamat, nomor yang bisa dihubungi, dan usur-unsur branding lainnya.

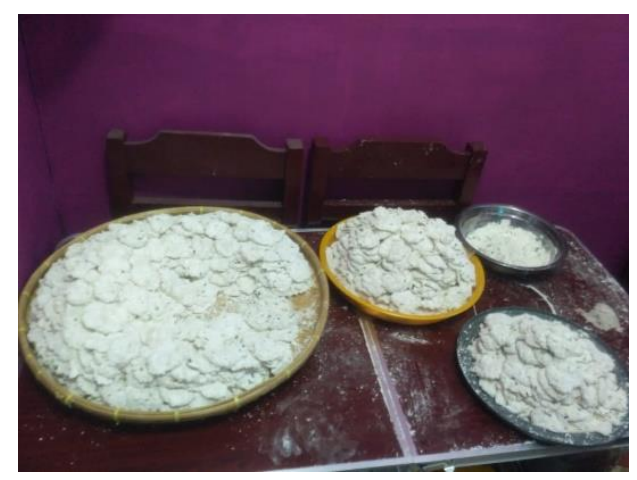

Gambar 1.

Produksi Produk Mitra

(Foto; Dokumentasi, Afriadi, 2019)

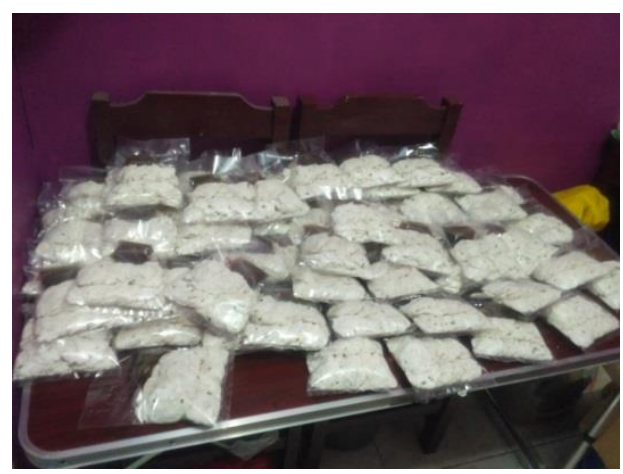

Hal| 53

\section{Gambar 2}

Produk Tidak Memiliki Merek Dagang

(Foto; Dokumentasi, Afriadi, 2019)

Dilihat dari kondisi di atas, maka dalam hal ini perlu dilakukan pendampingan untuk menciptakan branding dagang pada UKM yg dikelolah oleh Bapak Roni, sehingga produk yang dihasilkan memiliki identitas dan mudah dikenali oleh masyarakat, maka dalam hal ini perlu didatangkan pakar yang paham dalam bidang desain dan ekonomi UKM untuk menyelesaikan permasalahan ini, dengan tujuan utama supaya produk yang dihasilkan mitra menjadi leih baik lagi dan meningkatnya jumlah penjualan, sehingga secara tidak langsung meningkatkan kesejahteraan ekonomi usaha tersebut. 


\section{PEMBAHASAN}

\section{A. Desain Kemasan}

Kegiatan pengabdian ini lebih dititikberatkan kepada pendampingan sebuah desain kemasan, sebuah branding tidak lepas dari apa yang disebut dengan kemasan. Kemasan mempunyai peranan yang sangat utama dalam penjualan. Secara dasar kemasan berfungsi untuk menjaga produk dan membantu dalam promosi penjualan. Sebagai media atau menutupi, rancangan kemasan harus sesuai dengan sifat produk. Itu juga harus nyaman, menarik, ekonomis, komunikatif dan pastinya marketable. Berikut ini adalah fitur utama dari pengemasan yang baik:

\section{Nyaman}

Sebuah kemasan yang bagus harus memberikan kenyamanan bagi pemakainyanya, dimana harus dirancang sedemikian rupa sehingga produk dapat dengan mudah dibawa kemana saja dan dapat ditangani dengan mudah oleh penyalur atau pembeli. Size dan bentuk kemasan juga harus nyaman bagi penyalur untuk tetap di kedai atau bagi pembeli untuk tetap di rumah. Rancangan kemasan akan menarik apa bila dibuat dengan model pemakaian bisa berulang kali (Pranoto, 2020).

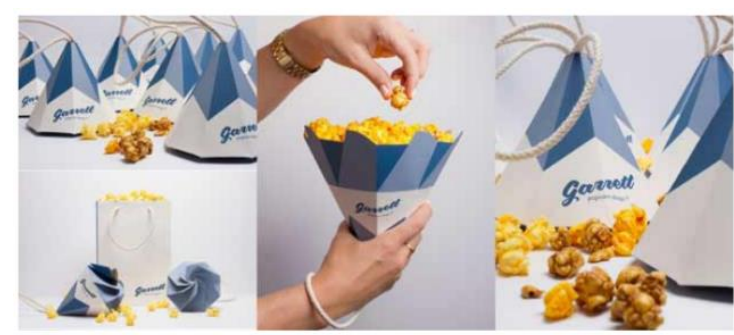

Gambar 3.

Desain Kemasan yang Nyaman (Foto; Dokumentasi, idekemasan, 2018)

2. Mampu Menarik Perhatian Orang

Hal ini merupakan hal yang sangat utama dari sebuah desain kemasan yang bagus. Kemasannya harus sangat menarik dan mempesona. Kemasan yang menarik akan mencuri perhatian pelanggan. Mampu 
menciptakan semangat mereka terhadap produk dan mendorong mereka untuk memilih produk. Warna, visual, desain, ukuran, dan lain sebagainya. Sebuah kemasan secara psikologis dapat merubah benak pelanggan, dari tidak ingin membeli menjadi ingin membeli. Berdasarkan riset pasar, beberapa pembelian pelanggan terjadi karena kemasan yang menghasilkan daya tarik kepada pembeli atau kepada konsumen. Kemasan yang baik mempunyai nilainilai keindahan. Hal ini akan menyerahkan rasa kenikmatan dan kebanggaan kepada konsumen yang membantu membangun nama baik dan status sosial masyarakat.

Sebaiknya seorang pedagang memperhitungkan posisi dan susunan kemasan saat diletakkan di etalase. Tampilan kemasan dan bahan Point of Purchase (рор) harus sesuai sehingga dapat menarik perhatian seseorang, mungkin yang awalnya orang tersebut tidak ingin membeli, namun setelah melihatnya ada rasa untuk memilikinya dan membeli barang tersebut. Alur cerita terkait suatu produk yang didesain sedemikian rupa akan mampu Hal 55 meningkatkan daya tarik dan sekaligus menghasikan kepercayaan pembeli. Susunan desain yang tidak kotor dan menarik adalah pilihan yang membuat pelanggan merasa bahwa produk tersebut memiliki nilai yang baik dan sehat tentuya (khusus untuk produk makanan atau minuman) (Pranoto, 2020).

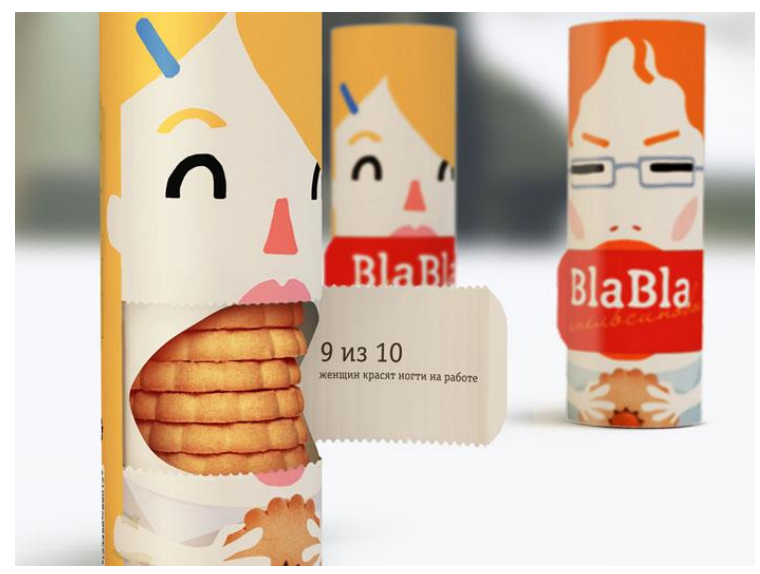

Gambar 4.

Desain Kemasan yang Mampu Menarik Perhatian Orang (Foto; Dokumentasi, Ayuprint, 2016) 


\section{Ekonomis}

Sebuah kemasan harus memilki nilai ekonomis. Harga yang dijual sebaiknya terjangkau bagi semua kalangan alias tidak mahal. Jika sebuah kemasan dijual dengan harga tinggi, hal ini tentu akan meningkatkan harga produk. Akibatnya, menjadi sulit untuk terjual. Jadi, pengemasan seharusnya tidak mahal dan tidak canggung. Pertimbangan ini bisa dilakukan dengan pemilihan material dan teknik cetak yang akan digunakan untuk diproduksi secara banyak. Disesuaikan dengan produk pengisinya, pengetahuan mengenai bahan kemasan menjadi sangat utama, sehingga bisa didapatkan material yang pas, efisien sekaligus mampu memenuhi kebutuhan dari sisi marketing sekaligus menjaga produk yang dijual menjadi aman (Pranoto, 2020).

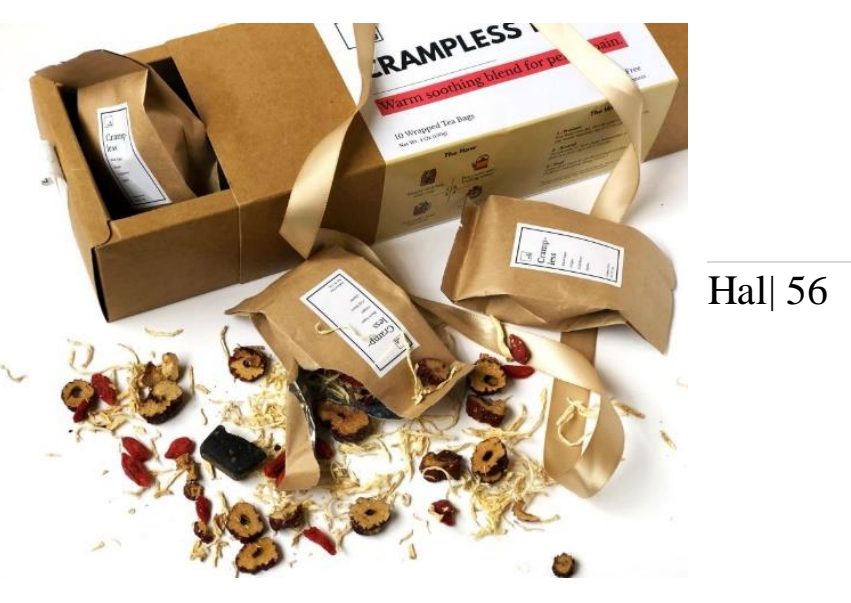

Gambar 5.

Desain Kemasan yang Bersifat Ekonomis (Foto; Dokumentasi, Pranoto, 2020)

\section{Melindungi}

Adapun yang menjadi tujuan dari pengemasan yaitu untuk menjaga produk dari berbagai risiko. Produk harus dikemas sedemikian rupa sehingga kualitas, kuantitas, warna dll. Produk tidak menurun atau rusak karena terkena sinar matahari, air hujan, tawon atau serangga, debu dan lain sebagainya. Sementara membawa dari tempat yang berbeda, mengangkut atau menyimpan, dan produk mungkin mendapatkan rusak atau busuk. Jadi, pengaturan yang tepat harus dibuat untuk menjaga produk dari setiap risiko kerusakan. Kemasan yang baik harus mampu melindungi dari: 1). 
Kerusakan alami: Hal ini disebabkan oleh hubungan produk dengan zat cair (seperti air, susu, dan lain sebagainya), gas dan asap, organisme mikrobiologi seperti bakteri, ragi dan jamur, panas, dingin, pengeringan (lingkungan kering di padang pasir dan daerah dataran tinggi), kontaminan dan serangga serta tikus, dan 2). Perlindungan fisik: Kemasan ini juga digunakan untuk menjaga fisik, yang diantaranya peningkatan perlindungan guncangan, perlindungan produk bagian dalam dan mengurangi kerusakan guncangan yang disebabkan oleh getaran, tersangkut, gesekan dan tendangan (Pranoto, 2020).

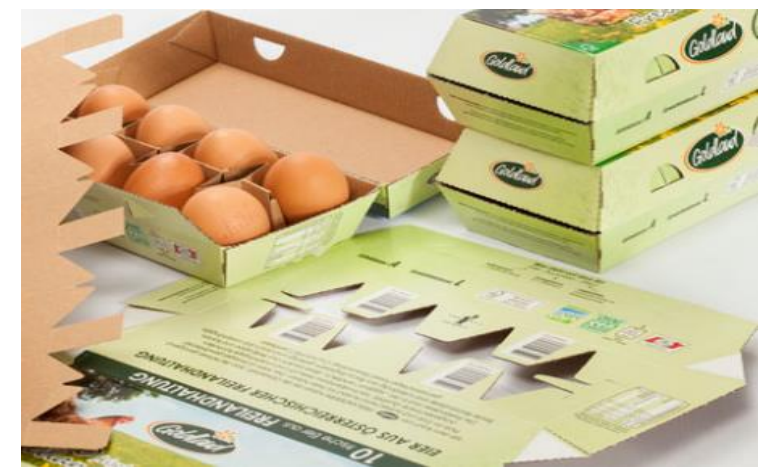

Gambar 6.

Desain Kemasan yang Mampu Melindungi (Foto; Dokumentasi, studio kemasan, 2015)

\section{Komunikatif}

Kemasan seharusnya juga memiliki sifat komunikatif, dimana sebuah kemasan mampu memberikan Hal| 57 informasi kepada konsumen tentang pesan merek dan kualitas produk, yang dapat menstimulus permintaan. Pengemasan yang baik berfungsi sebagai silent sales force dan reklame yang efektif. Kemasan tersebut menyampaikan informasi yang diperlukan kepada konsumen. Informasi umum yang diberikan oleh kemasan mencakup fitur umum produk, bahan, berat bersih isi, nama dan alamat produsen, harga eceran maksimum (MRP). Pengemasan obatobatan dan beberapa produk makanan, dan minuman diperlukan untuk memberikan informasi tentang tahapan-tahapan persiapan, resep, dan ide penyajian, manfaat gizi, dan tanggal pembuatan, tanggal kadaluwarsa, pesan peringatan dan informasi peringatan. Terkadang, warna kemasan itu sendiri memberikan 
banyak informasi penting yang harus diketahui oleh pembeli. Misalnya, warna oranye dari botol Mirinda atau Fanta menyampaikan informasi bahwa merek-merek ini adalah minuman ringan berwarna oranye.

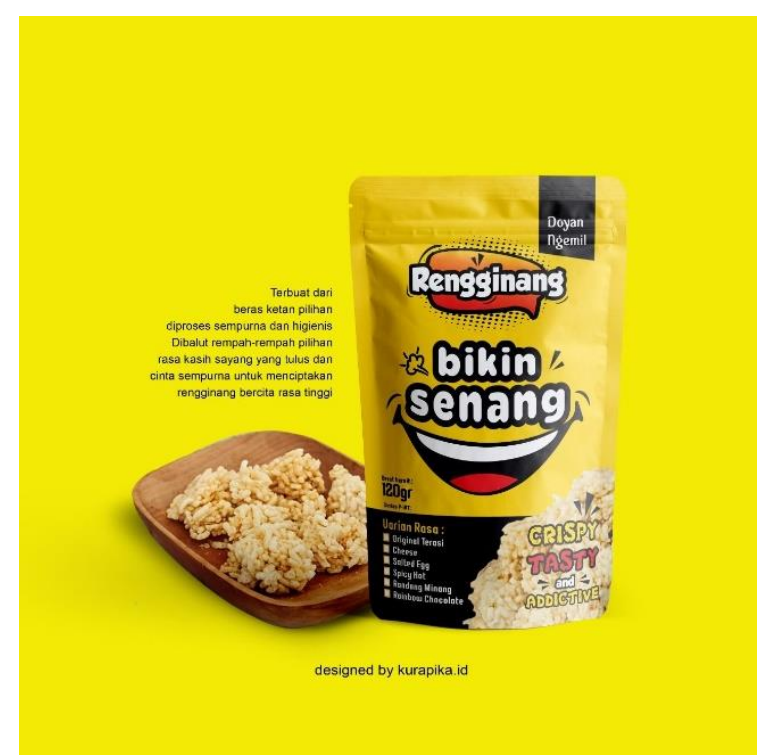

Gambar 7.

Desain Kemasan yang Memberikan Kesan Komunikatif

(Foto; Dokumentasi, kurapikaid, 2021)

Setelah dijelaskan tentang materi di atas maka tim kegiatan pengabdian kepada masyarakat melakukan kegiatan pada UKM di Kecamatan Percut Sei Tuan, sebanyak satu kelompok usaha rumahan yang dikelola Bapak Roni, kegiatan ini dilaksanakan selama 2 hari, pada hari pertama dilakukan kegiatan pendampingan, sosialisasi, dan edukasi Hall 58 tentang merek dagang. Selama kegiatan berlangsung kelompok ini sangat antusias, hal ini terbukti dengan keseriusan Bapak Roni dan anggotanya dalam mengikuti kegiatan ini.

Peserta berperan aktif dalam mengikuti kegiatan ini mulai dari hari pertama hingga hari terakhir. Sebelum pelatihan maupun workshop dimulai, dibutuhkan persiapan yang matang agar segala proses kegiatan yang sudah direncanakan dapat terukur (Alamo, 2018: 41).

Hal ini dapat dilihat dari perhatian yang diberikan oleh semua anggota kegiatan selama kegiatan berlangsung. Semua peserta mengikuti kegiatan mulai dari a). Focus Group Discussion (FGD) mengenai kegiatan Pengabdian Kepada Masyarakat; b). Semua peserta mengikuti sosialisasi dan pendampingan dalam kegiatan 
pengenalan pengetahuan tentang diinginkan, kadangkala ada sebagian pentingya sebuah merek dagang; dan desain yang menuntut salah satu dari c). Semua peserta mengaplikasikan unsur-unsur desain harus diutamakan, proses pembuatan atau pencetakan jadi ada penekanan-penekanan dalam Hal| 59 merek dagang.

\section{B. Unsur-Unsur dan Prinsip-} Prinsip Desain setiap unsur. Berikut merupakan unsur-unsur desain grafis dan prinsipnya:

Merek dagang yang dibuat

\section{Line}

tentunya dengan berbagai Line atau garis merupakan unsur pertimbangan unsur-unsur desain serta prinsip-prinsipnya. Berdasarkan kepakaran yang dimiliki oleh salah satu tim kegiatan ini yang merupakan seorang desain grafis, maka peralatan utama yang harus dimiliki adalah sebuah ide serta kemampuan untuk menuangkan pikiranya ke dalam sebuah desain kemasan, seorang desainer yang baik tentu ingin memaksimalkan sebuah kaya seni yang dihasilkan, sehingga mitra dalam kegiatan pengabdian ini merasa desain yang dirancang tersebut layak untuk digunakan dalam produk mitra tersebut. Pengerjaan sebuah desain, tergantung bagaimana hasil yang 
Menurut Badriya (2016), ketebalan, akan menimbulkan hasil mengungkapkan 1). Garis lurus, garis yang berbeda. Penggunaan garis dalam lurus biasanya diidentikan dengan kesan kaku, variasi ini biasanya digunakan sebagai simbol formalitas, 2). Garis lengkung, penggunaan garis lengkung biasanya memberikan kesan lembut dan luwes, 3). Garis zigzag, garis zigzag sering dimaknai sebagai garis yang keras sekaligus dinamis, 4). Garis tidak beraturan, garis ini bisanya menimbulkan kesan fleksibel dan informal, 5). Garis horizontal, horizontal melambangkan kesan pasif, 6). Garis vertikal, vertikal sering dimaknai sebagai bentuk garis yang memiliki kesan stabil, dan 7). Garis diagonal, garis ini dapat diartikan sebagai makna aktif, dinamis dan menarik perhatian.

$$
\text { Pemakaian garis dapat }
$$

memberikan komparasi dalam rasa dan juga dalam meransang ataupun mengeksekusi sebuah gagasan atau pemikiran baru. Contohnya saja dengan mengubah tekanan, lekukan, desain grafis tidak terikat dengan aturan dan pakem tertentu, karena Hal| 60 pada dasarnya line merupakan sebuah unsur visual yang dapat dipakai dimana dan kapan saja.

Line dalam penggunaanya, sebuah garis perlu memperhitungkan secara teliti, hasilnya tidak terkesan abal-abal dan dipaksakan. Penggunaan berbagai macam garis yang spontan akan menambah unsur keindahan dan kenangan untuk orang yang melihat. Karena tujuan dari desain komunikasi visual sendiri adalah untuk menyajikan informasi baik verbal maupun gambar agar dapat sampai dengan mudah kepada pembaca atau penikmat desain.

\section{Bidang, Tekstur, dan Space}

Bidang merupakan segala bentuk apapun yang memiliki dimensi tinggi dan lebar, adapun bentuk-bentuk bidang sebagai berikut: (lingkaran, segitiga, segiempat, elips, setengah 
lingkaran, dan sebagainya. Bidang juga memiliki bentuk-bentuk yang tidak beraturan. Bidang geometris memiliki kesan yang formal, sedangkan bidang non geometris memiliki kesan yang lebih dinamis dan tidak formal. Dalam desain grafis tekstur adalah nilai halus dan kasarnya sebuah benda, atau juga bisa disebut nilai raba. Penggunaanya dapat dimayakan untuk memberikan visual yang berkesan dan berkarakter. Dalam sebuah desain komunikasi visual tekstur sering digunakan untuk mengatur keseimbangan dan kontras. Pada prakteknya tekstur sering dikategorikan sebagai corak dari suatu permukaan benda, misalnya permukaan karpet, baju, kulit, kayu, dan sebagainya. Penggunaan tekstur dalam desain grafis juga biasanya sering diaplikasikan pada latar desain atau sering kita sebut background desain. Ruang atau space merupakan jarak anatara suatu bentuk dengan bentuk yang lainnya, yang pada desain grafis biasanya dapat dijadikan sebagai unsur pemberi efek estetika desain. Dalam pengertian desain grafis area yang kosong yang berada diantara elemen-elemen visual Hal| 61 juga dianggap sebagai elemen desain. Bidang kosong dimaksudkan untuk menambah kesan nyaman dan "istirahat" serta memberikan kesan tekanan kepada objek visual yang ada dalam sebuah desain (Badriya, 2016).

\section{Size dan Warna}

Ukuran adalah unsur lain dalam desain grafis yang mendefinisikan besar kecilnya suatu objek. Unsur ini digunakan untuk memperlihatkan objek manakah yang kita mau tonjolkan karena dengan menggunakan unsur ini seorang desainer grafis akan dapat menciptakan kontras dan penekanan (emphasis) pada objek desain sehingga orang akan tahu skala prioritas objek yang akan dilihat terlebih dahulu dibandingkan yang lainnya, misalnya saja untuk ukuran suatu judul akan lebih besar dari skala 


\section{Jurnal Batoboh, Vol 6 , No 2, Maret 2021}

Adek Cerah Kurnia Azis, Putri Sari Margaret Julianty Silaban,

Pebri Hastuti, Revita Yuni

objek yang lainnya. Warna adalah elemen dari unsur desain grafis yang menjadi penarik perhatian paling utama. Penggunaan warna yang tepat akan berbanding lurus dengan kualitas, citra, keterbacaan, dan penyampaian pesan dalam desain tersebut. semisal adalah untuk penggunaan warna yang lembut akan memancarkan kesan romantis, kedamaian, dan kenyamanan. Sedangkan warna-warna tegas dan terang akan memberi kesan dinamis. Menghindari memadukan warna yang salah adalah sangat penting untuk menjauhi penafsiran yang salah oleh orang yang melihatnya (Badriya, 2016).

Adapun dampak dari kegiatan Pengabdian Kepada Masyarakat ini sebagai berikut: a). Mitra sudah memiliki merek dagang yang menarik, dimana sebelumnya hanya menggunakan plastik polos saja, dan b). Mitra dapat memahami betapa pentingnya sebuah merek dagang dalam usaha, sebagai media promosi dan meningkatkan daya tarik pembeli.

Melalui kegiatan pelatihan ini sekaligus memberikan ruang ekspresi, pengembangan imajinasi dan Hal| 62 kreativitas kepada mitra untuk lebih produktif lagi (Zaitun, 2016: 35).

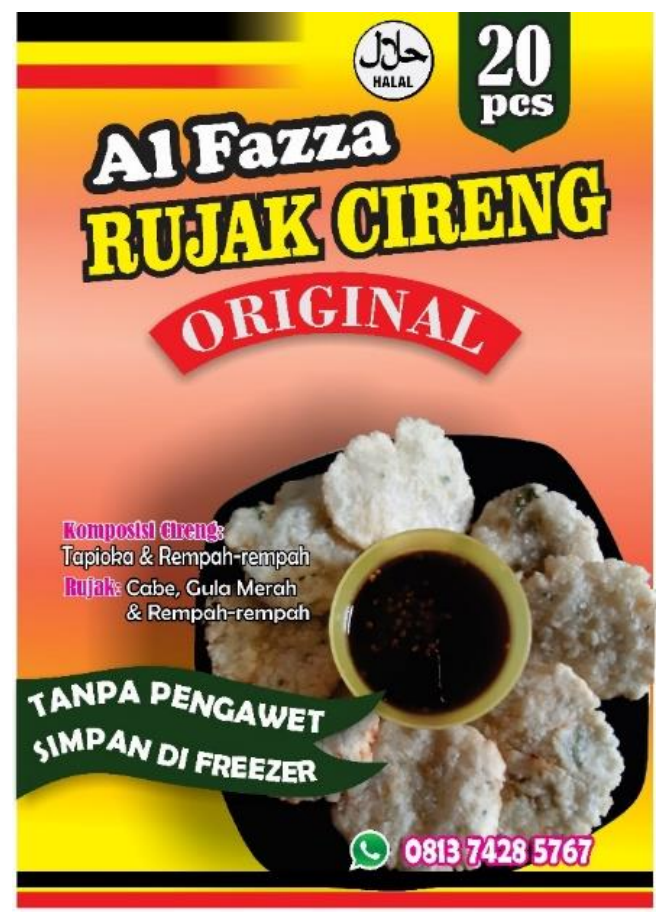

Gambar 8.

Merek Rujak Cireng

(Foto; Dokumentasi, Azis, 2019) 


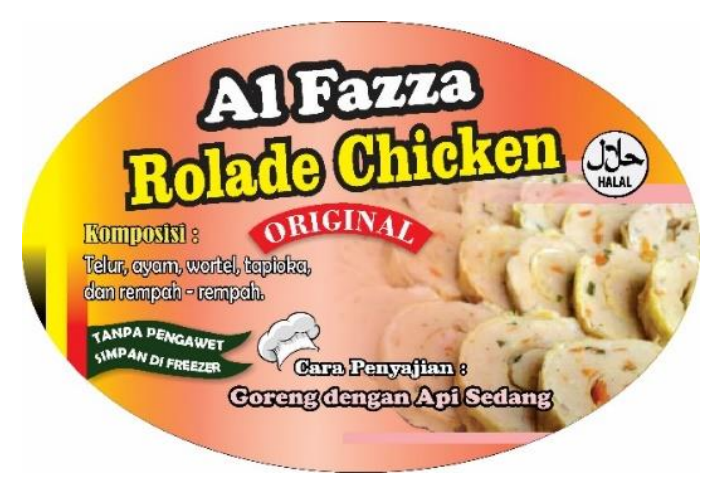

Gambar 9.

Merek Rolade Chicken

(Foto; Dokumentasi, Azis, 2019)

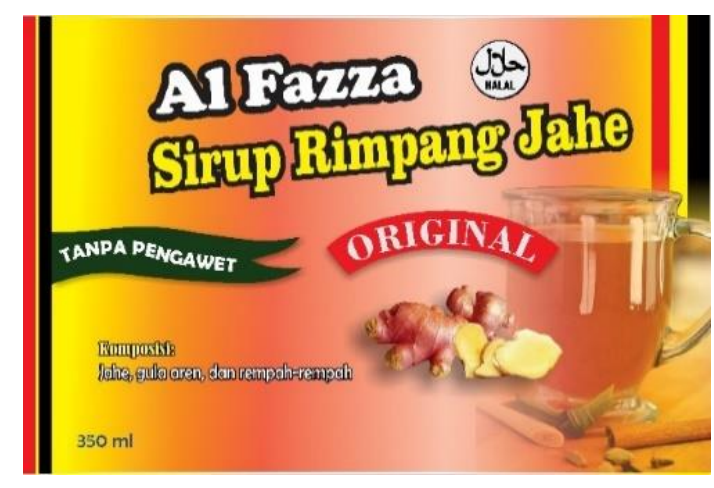

Gambar 10.

Merek Sirup Rimpang Jahe (Foto; Dokumentasi, Azis, 2019)

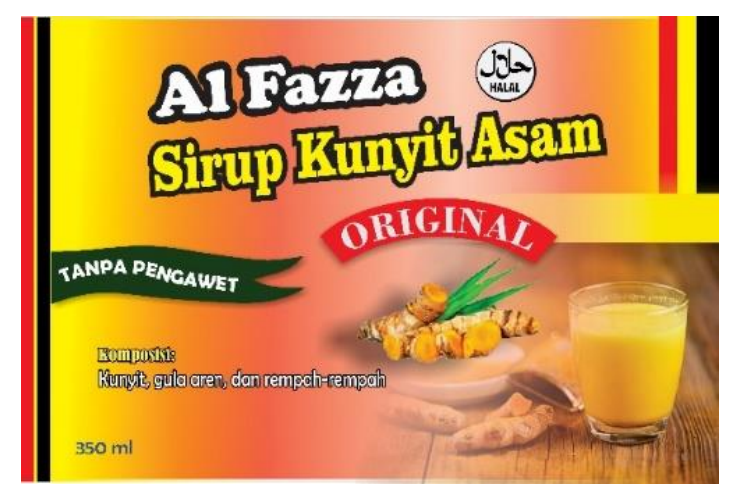

Gambar 11.

Merek Sirup Kunyit Asam (Foto; Dokumentasi, Azis, 2019)

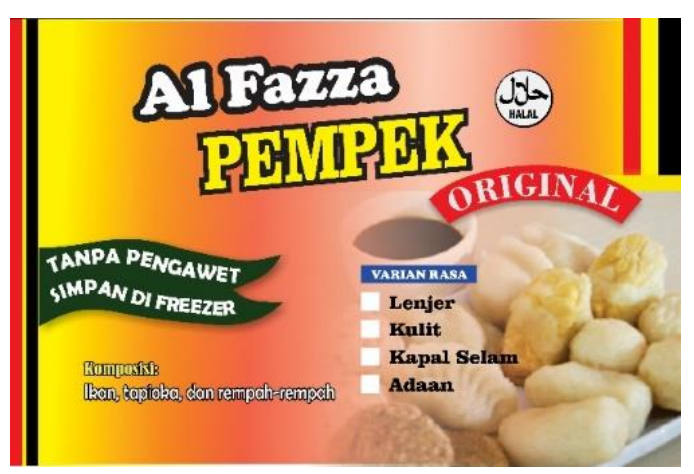

Gambar 12.

Merek Pempek

(Foto; Dokumentasi, Azis, 2019)

Berdasarkan hasil pembahasan terdiri atas beberapa permasalahan yang dihadapi oleh mitra, maka dapat disimpulkan sebagai berikut berdasarkan uraian tersebut di atas.

\section{SIMPULAN}

Berdasarkan permasalahan yang dihadapi oleh mitra sebelumnya produk yang dihasilkan masih belum memiliki merek dagang, dengan kondisi ini mitra kurang confidence dalam mempromosikan poduknya yaitu aneka makanan dan minuman seperti; Rujak Cireng, Rolade Chicken, Sirup Rimpang Jahe, Sirup Kunyit Asam, dan Pempek. Setelah dilakukannya kegiatan Pengabdian Kepada Masyarakat yang dilaksanakan 
oleh dosen Universitas Negeri Medan dalam bidang merek dagang, maka dihasilkan berbagai macam merek dagang yang menarik. Dalam merek dagang tersebut diuraikan jelas semua kebutuhan promosi mulai dari nama dagang, ilustrasi, komposisi, slogan, nomor yang bisa dihubungi, alamat, dan informasi penting lainnya. Hal ini menunjukkan bahwa mitra sudah bisa pecaya diri mempromosikan produknya dan menerapkan ilmu yang sudah diberikan selama pelatihan tersebut.

\section{KEPUSTAKAAN}

Afriadi, Roni. (2019). “Proses Produksi dan

Pengemasan Produk". Hasil

Dokumentasi Pribadi: 09 Juni 2019,

Rumah Produksi Desa Sei Rotan. Alamo, E., Susanti, D., \& Saaduddin, S. (2018). Pelatihan Kelompok Sandiwara dan Pemantapan Manajemen Kelompok di Kelurahan Ganting
Padangpanjang, Sumatera

Barat. Batoboh, 3(1), 37-47.

Ayuprint. (2016). 42 Contoh Kemasan

Terbaik dengan Desain Kreatif Hal| 64

untuk Inspirasi Produk Anda.

https://ayuprint.co.id/42-contoh-

kemasan-terbaik-dengan-desain-

kreatif-untuk-inspirasi-produkanda/ (diakses tanggal 06 April 2021).

Azis, A. C. K. (2019). “Desain Merek

Dagang Mitra". Hasil

Dokumentasi Pribadi: 20 Juni 2019, Jurusan Seni Rupa Universitas Negeri Medan.

Badriya, Yaya. (2016). Unsur-unsur

Desain

Grafis dan Prinsipnya.

https://ilmuseni.com/seni-

rupa/seni-grafis/unsur-desaingrafis (diakses tanggal 06 April 2021).

Idekemasan. (2018). Contoh Desain

Kemasan

Makanan Simple.

https://idekemasan.blogspot.com 
/2018/03/contoh-desain-

kemasan-makanan-simple.html

(diakses tanggal 06 April 2021).

Kurapikaid. (2020). Desain Kemasan YK.

https://id.pinterest.com/kurapika

id/ created/ (diakses tanggal 06

April 2021).

Pranoto, Eko. (2020). Memahami Desain

Kemasan.https://www.printgraph

icma

gz.com/2020/04/28/memahami-

desain-kemasan/ (diakses

tanggal 06 April 2021).

Studiokemasan. (2015). Inspirasi Desain

Kemasan.

http://studiokemasan.blogspot.c

om/2015/06/eggyplay-bermain-

dengan-kemasan-telur.html

(diakses tanggal 06 April 2021).

Wikipedia. (2018). Desa Sei Rotan.

https://id.wikipedia.org/wiki/Sei

_Rotan,_Percut_Sei_Tuan,_Deli_
Serdang (diakses tanggal 28

Februari 2021).

Zaitun, K., Surya, W., Mahendra, B., \&

Saputra, D. (2016). Pelatihan

Hal| 65

Mendongeng dan Bercerita Bagi

Pelajar dan Guru Se

Bukittinggi. Batoboh, 1(1), 31-44. 